Volume 4, Number 1, 2018

\title{
Physical Modeling of Thermal Processes of the Air Solar Collector with Flow Turbulators
}

\author{
Vasyl Zhelykh, Khrystyna Kozak ${ }^{*}$, Olexandra Dzeryn, Volodymyr Pashkevych \\ Lviv Polytechnic National University, 12 S. Bandery St., Lviv, 79013, Ukraine
}

Received: March 12, 2018. Revised: April 16, 2018. Accepted: April 27, 2018.

(c) 2018 The Authors. Published by Lviv Polytechnic National University.

\begin{abstract}
The analysis of existing systems of solar air heating has been carried out. The physical model of the solar air collector (SAC) with additionally installed flow turbulators, which are located in the air channel of the solar collector, is presented to improve its thermal characteristics and efficient use in temperate climates. The energy balances for the five key elements of the SAC have been presented and the balance equations system has been written. To determine the geometrical and heat engineering parameters of the flow turbulators, a number of graphical dependencies have been recorded. We found out that in the air channel of the solar collector there is a transitional movement of the heat carrier, and the maximum coefficient of convective heat exchange between the turbulator of flow and air is observed at the angle of inclination of the heat absorber of $45 \mathrm{deg}$. The computer simulation of thermal processes occurring in the air channel of the solar collector was carried out and we discovered that the power of the proposed SAC increased by $23 \%$ compared to the solar collector with a flat heat-absorbing plate.
\end{abstract}

Keywords: solar air collector; physical model; flow turbulator; coolant (transfer medium); air duct.

\section{Introduction}

It is a well known fact that the thermal condition of the premises depends on the efficiency of the heating system. As a result, the cost of heating the buildings is a large part of the budget to maintain comfortable conditions in buildings and facilities. Thus, heat supply systems consume about $30-40 \%$ of Ukraine's energy resources from their total quantity. This necessitates the development of special systems for maintaining the thermal regime in the premises that allow reducing the share of traditional energy resources. The promising direction of developing such energy-saving systems is the introduction of air heating which is based on devices that use renewable energy sources, in particular solar energy.

There are many constructive options for solar air heating systems that are classified according to their purpose, the way in which the solar collector is located, the nature of the coolant movement, the presence of a thermal accumulator, etc. The leaders in the introduction of such systems are Switzerland, Japan and Canada. Ukraine has good prospects for the effective use of such equipment since the average annual potential of solar energy in Ukraine is quite high, about $1235 \mathrm{kWh} / \mathrm{m}^{2}$, and higher than, for example, in Germany and Poland $\left(1080 \mathrm{kWh} / \mathrm{m}^{2}\right)$, where the use of heliosystems is fairly common [1]. Along with reliability, corrosion resistance, durability and relatively low cost, compared to solar water heating systems, such systems require careful selection of solar collector design, heat absorber form, effective installation angle and heat accumulative material.

\footnotetext{
${ }^{*}$ Corresponding author. Email address: cr i@ukr.net
}

This paper should be cited as: V. Zhelykh, K. Kozak, O. Dzeryn, V. Pashkevych. Physical modeling of thermal processes of the air solar collector with flow turbulators. Energy Eng. Control Syst., 2018, Vol. 4, No. 1, pp. 9 - 16. https://doi.org/10.23939/jeecs2018.01.009 


\section{The purpose and objectives of the study}

To substantiate the physical model of the thermal processes of the air solar collector with flow turbulators executed in the form of a circular twisted conoid, and motivate the use of this form of heat absorbent.

\section{Analysis of Existing Data}

As of 2009, the production of air solar collectors was carried out by 30 large firms in 14 countries of the world [2] with a total annual program of 106 thousand $\mathrm{m}^{2}$. The center for producing this equipment is Canada, which produces more than half of the world's total number of SACs - $65201 \mathrm{~m}^{2}$ in 2009 [3]. According to a review of the global solar heating market by the International Energy Agency (May 2013), at the end of 2011, air junctions with an overall area of 22134432 square meters were operating in the world, including a majority $\left(71 \%, 156,859 \mathrm{~m}^{2}\right)$ with uncontaminated flat air collectors. Glacial solar collectors are in $29 \%$ of cases $\left(644885 \mathrm{~m}^{2}\right)$.

By designation, the solar air heating system (SAHS) can mainly be divided into three groups that have a number of common features. The first group includes active heat supply systems with a thermal battery to cover the thermal load at night and in the period of high clouds (Fig. 1, a) - usually used for heating and ventilation of rooms with background heating and daytime occupancy of people (usually administrative premises). This group can be used effectively in soft climates. The second group includes solar heating systems, which work by means of free convection, that is, passive systems (Fig. 1, b). As a rule, the solar collector of such a system is built into the design of the external protection of the building. Systems of the second group are used for heating large premises and are distributed in the countries of North America. The third group integrates heliosystems for industrial technologies with the need for large volumes of hot air, usually for drying agricultural products (cereals, mushrooms, fruits, herbs, etc.). Such systems are essentially simplified systems of the first group, usually active, can be mobile, without accumulation and additional energy sources, distributed in the southern solar countries of Asia (India, China, Uzbekistan, etc.) [4].

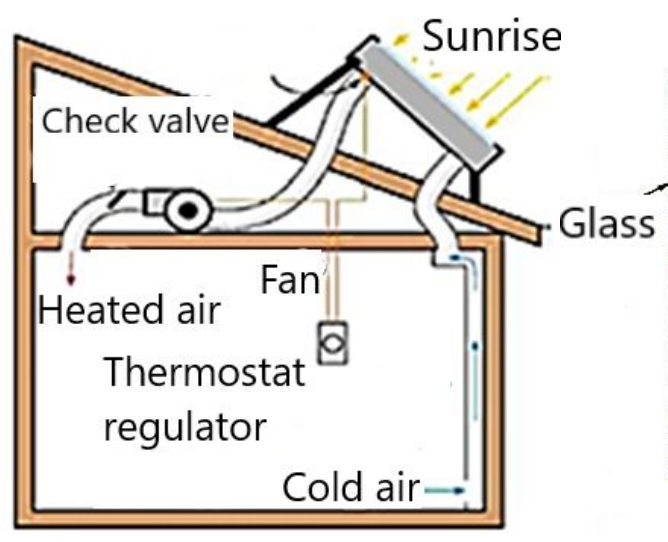

a)

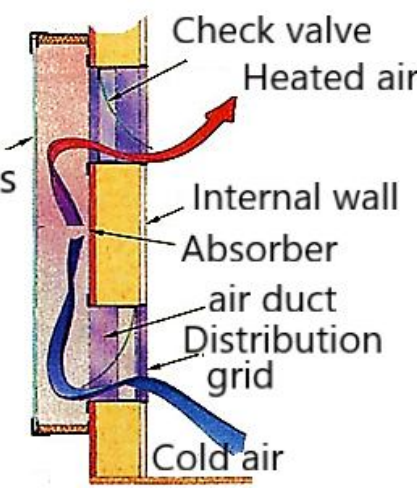

b)

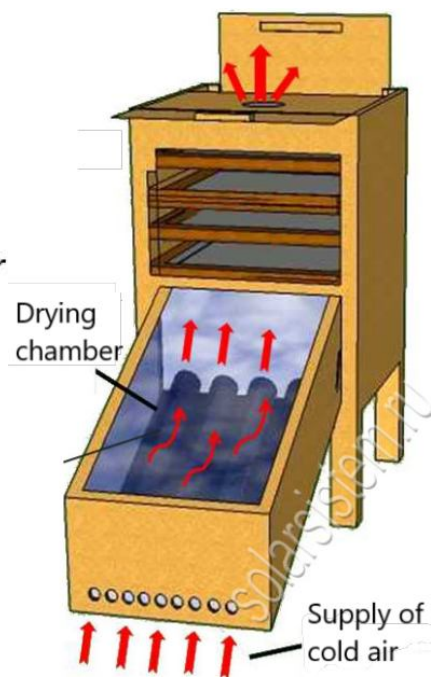

c)

Fig.1. Air systems for solar air heating:

a) an active system; b) passive system (thermosyphon); c) an active system for drying agricultural products.

Based on this analysis, we can conclude that there is still a need to develop a design of a solar air collector with an effective form of heat absorber, the technological practice of its use in temperate climates, as well as in-depth research on heat transfer for these operating conditions.

\section{The Experiments and Their Analysis}

By carrying out a detailed analysis of existing types of solar air heating systems and solar collector designs, it was decided to use air flow turbulators as a supplementary heat absorber made in the form of a screw (circular twisted conoid) and placed in the air channel of the solar collector at a certain distance from each other along the motion of the coolant. The idea was that the shape of the heat absorbent should be as close as possible to the cylinder, which would absorb the sun's beam at any angle of its incidence on the plane. Since the placement of cylinders in the air 
channel will create a significant resistance to the movement of the coolant, it was agreed to use a screw form. In addition, turbulators of the flow can provide intensification of heat exchange processes in the air channel of the SAC. Since this solar collector operates on the principle of free convection, the flow turbulators are stationary, to reduce the pressure loss in the air channel $[5,6]$.

A physical model describing SAC with consideration of variables physical properties its characteristic zones was developed. In this model, the limited volume of solar collector is analyzed, which is divided into five knots, perpendicular to the direction of air movement in the air channel: glass plate, air, turbulators of air flow, heatabsorbing plate, thermal insulation (Fig. 2).
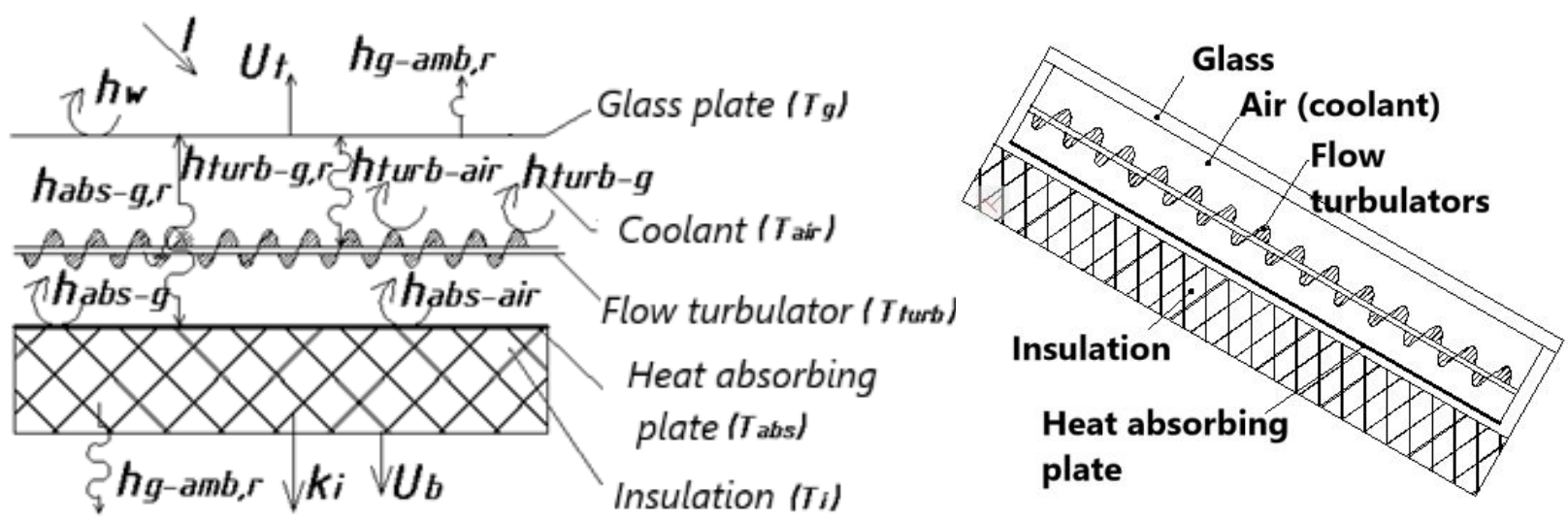

Fig.2. Physical model of air solar collector consisting of five knots.

The basic equations describing the thermal processes for each node were obtained by applying the total energy balance in a limited volume of the solar collector. For a one-dimensional heat transfer, the energy balance as as follows $[7,8]$ :

$$
\frac{\partial U}{\partial t}=Q_{u}+Q_{l}+Q_{S}
$$

where $\partial U / \partial t$ is change of internal energy; $Q_{u}$ is change of internal energy; $Q_{l}$ is lost energy; $Q_{S}$ is flow of heat accumulated by the solar collector, $\mathrm{W}$.

The following simplifications were made for the analysis $[7,8]$ :

1) The loss of heat from the collector's side walls is negligible and can be neglected;

2) Characteristics of glass and thermal insulation do not depend on temperature changes, that is, they are stable;

3) The thermophysical characteristics of the air and the heat-absorbing plate are temperature dependent;

4) Radiation and environmental conditions are time-dependent;

5) Losses through the front and back of the collector occur at the same ambient air temperature;

6) The sky can be regarded as an entirely black body for long-wave radiation at the equivalent temperature of the sky;

7) The influence of dust and dirt contained on the collector is not taken into account;

8) The temperature of the heat-absorbing plate and the turbulators of the flow is equal.

Glass. Given the small thickness of glass, it is advisable to take its temperature unchanged. Heat flows through the glass to the environment, by convection from the heat-absorbing surfaces and into the environment, from the heatcarrier. Radiant heat transfer takes place in the environment, from the sun and heat-absorbing surfaces.

Then formula 1 can be written as follows:

$$
C_{g} \cdot m_{g} \cdot \frac{d T_{g}}{d t}=\left[h_{g-a m b r}\left(T_{a m b}-T_{g}\right)+h_{w}\left(T_{a m b}-T_{g}\right)+h_{a b-g, r}\left(T_{g}-T_{a b}\right)+h_{t u r b-g . r}\left(T_{g}-T_{t u r b}\right)+\alpha I\right] F_{a b s},
$$

where $h$ is heat transfer coefficient, $\mathrm{W} /\left(\mathrm{m}^{2} \cdot \mathrm{K}\right) ; \quad \alpha$ is absorption coefficient; $I$ is thermal flux of solar radiation, W/ $\mathrm{m}^{2}$; $F$ is area of the heat absorbing plate, $\mathrm{m}^{2}$.

Index: $a m b$ is environment; $g$ is glass cover; air is air; turb is flow turbulator; $r$ is radiant heat exchange; $c$ is convection. 
Coefficient of convective heat exchange between glass and external air, $h_{w}, \mathrm{~W} /\left(\mathrm{m}^{2} \cdot \mathrm{K}\right)$, is determined from the equation:

$$
h_{w}=5.7+3.8 \cdot V
$$

where $V$ is air velocity on the surface of the glass plate, $\mathrm{m} / \mathrm{s}$.

The coefficient of radiant heat transfer from glass to the environment, $h_{g-a m b, r}, \mathrm{~W} /\left(\mathrm{m}^{2} \cdot \mathrm{K}\right)$, equals:

$$
h_{g-a m b, r}=\frac{\sigma \cdot \varepsilon_{g}\left(T_{g}+T_{s k y}\right)\left(T_{g}^{2}+T_{s k y}^{2}\right)\left(T_{g}-T_{s k y}\right)}{T_{g}-T_{a m b}},
$$

where $\sigma=5.67 \times 10^{-8}$ is the Stefan-Boltzmann constant, $\mathrm{W} /\left(\mathrm{m}^{2} \cdot \mathrm{K}^{4}\right) ; \varepsilon_{g}$ is the degree of blackness of the glass $\left(\varepsilon_{g}=0.85\right) ; T_{s k y}=\left(T_{a m b}-6\right)$ is temperature of the skies, $\mathrm{K}[8]$.

The coefficient of radiant heat exchange between the heat absorbing plate and the glass, $h_{a b s-g, r}, \mathrm{~W} /\left(\mathrm{m}^{2} \cdot \mathrm{K}\right)$, is determined by the formula:

$$
h_{a b s-g, r}=\frac{\sigma \cdot\left(T_{a b}^{4}-T_{g}^{4}\right)}{\left(\frac{1}{\varepsilon_{g}}+\frac{1}{\varepsilon_{a b}}-1\right)},
$$

where $\varepsilon_{a b}$ is the degree of blackness of the surface of the heat-absorbing plate, $\varepsilon_{a b}=0.95 ; T_{a b}$ is temperature of the heat absorber, K.

The coefficient of radiant heat exchange between the flow turbulator and the glass, $h_{t u r b-g, r}, \mathrm{~W} /\left(\mathrm{m}^{2} \cdot \mathrm{K}\right)$, equals:

$$
h_{t u r b-g, r}=\frac{\sigma \cdot\left(T_{t u r}^{4}-T_{g}^{4}\right)}{\left(\frac{1}{\varepsilon_{g}}+\frac{1}{\varepsilon_{t u r b}}-1\right)},
$$

where $\varepsilon_{t u r b}$ is degree of blackness of the surface of the flow turbulator, $\varepsilon_{t u r b}=0.95 ; T_{t u r b}$ is temperature of the flow turbulator surface, $\mathrm{K}$.

Heat-absorbing plate. Applying the energy balance for the absorber zone, taking into account the changing properties of the heat absorber, and also taking into account the intensity of solar radiation in a limited volume of the collector, the radiation between the absorber and the glass plate, the thermal interaction between the heat absorber and the insulation and heat transfer by convection to the working body, we obtain the following equation:

$$
C_{a b s} \cdot m_{a b s} \cdot \frac{d T_{a b s}}{d t}=\left[h_{a b s a i r}\left(T_{a i r}-T_{a b s}\right)+\frac{k_{i}}{\delta_{i}}\left(T_{i}-T_{a b s}\right)+h_{g-a b s r}\left(T_{g}-T_{a b s}\right)+S\right] \cdot F_{a b s},
$$

where $S$ is the energy of solar radiation absorbed by the SAC is calculated by the formula [9]:

$$
S=\left[I_{b} \cdot P_{b}(\tau \alpha)+I_{d} \cdot P_{d}(\tau \alpha)\right],
$$

where $I_{b}$ is the intensity of direct solar radiation that falls on a horizontal surface, $\mathrm{W} / \mathrm{m}^{2} ; I_{d}$ is the intensity of scattered solar radiation that falls on a horizontal surface, $\mathrm{W} / \mathrm{m}^{2} ; P_{b}, P_{d}$ are coefficients of the SAC position for direct and diffused radiation (tabular value); $\tau \alpha$ is corrected absorption capacity.

$$
P_{d}=\cos ^{2} \frac{\beta}{2}
$$

where $\beta$ is angle of inclination of the solar collector, degree.

The coefficient of radiant heat exchange between the heat absorbing plate and the glass, $h_{a b s-g, r}, \mathrm{~W} /\left(\mathrm{m}^{2} \cdot \mathrm{K}\right)$, equal:

$$
h_{a b-a i r}=\frac{k \cdot N u}{D_{h}}
$$

where $D_{h}$ is hydraulic diameter of the air channel, $\mathrm{m}$.

For a channel with a rectangular section, the hydraulic diameter, $D_{h}, \mathrm{~m}$, is determined by the formula [10]: 


$$
D_{h}=\frac{4 a b}{2(a+b)},
$$

where $a$ and $b$ are respectively, the height and width of the air channel, $\mathrm{m}$.

If the mode of movement of the coolant in the air channel is laminar, that is $\operatorname{Re} \leq 5 \cdot 10^{5}, \operatorname{Pr} \geq 0.5$ :

$$
N u=0.664 \mathrm{Pr}^{1 / 3} \cdot \mathrm{Re}^{1 / 2} .
$$

For the turbulent mode of movement of the coolant $\left(5 \cdot 10^{5}<\operatorname{Re}<10^{8}, 0.6<\operatorname{Pr}<60\right)$ :

$$
N u=0.033 \operatorname{Re}^{0.8} \cdot \operatorname{Pr}^{0.33} \text {. }
$$
formula:

The Reynolds criterion, which characterizes the regime of motion of a liquid, is determined by the following

$$
\operatorname{Re}=\frac{w \cdot D}{v_{C}},
$$

where $D$ is the equivalent diameter of the air channel, $\mathrm{m} ; w$ is flow rate of the coolant in the channel, $\mathrm{m} / \mathrm{s} ; v_{C}$ is kinematic viscosity of air, $\mathrm{m}^{2} / \mathrm{s}$.

Turbulator flow. For power turbulators, the energy balance will be as follows:

$$
C_{\text {turb }} \cdot m_{\text {turb }} \cdot \frac{d T_{\text {turb }}}{d t}=\left[h_{\text {turb-air }}\left(T_{\text {turb }}-T_{\text {air }}\right)+h_{g-t u r b, r}\left(T_{g}-T_{a b s}\right)+I(\tau \alpha)\right] F_{\text {turb }} \cdot n,
$$

where $n$ is number of turbulators; $F_{\text {turb }}$ is surface area of the flow turbulator, $\mathrm{m}^{2}$.

Coefficient of convective heat exchange between the flow turbulator and heat carrier, $h_{\text {turb-air }}, \mathrm{W} /\left(\mathrm{m}^{2} \cdot \mathrm{K}\right)$, is determined by the equation formula:

$$
h_{\text {turb-air }}=\frac{N u \cdot k_{\text {air }}}{\delta} .
$$

For the angle of installation of the solar collector $15 \leq \beta \leq 75$ degree, $N u_{\text {air }}$ number is determined by the formula, submitted by Holland in 1976 [10]:

$$
N u_{a i r}=1+1.44 \cdot\left[\frac{1708 \cdot\left(\sin (1.8 \beta)^{1 / 6}\right.}{R a \cos (\beta)}\right] \cdot\left(1-\frac{1708}{R a \cos (\beta)}\right)^{+}+\left[\left(\frac{R a \cos (\beta)}{5830}\right)^{1 / 3}-1\right]^{+} .
$$

Relay number:

$$
R a=\frac{\rho^{2} \cdot c_{a i r} \cdot g \cdot B \cdot\left(T_{\text {turb }}-T_{a i r}\right) \cdot \delta^{3}}{v_{\text {air }} \cdot \lambda}
$$

For installation angle $\beta=90$ degree:

$$
N u_{90}=0.0605 \cdot R a^{1 / 3},
$$

where $N u$ is Nusselt number; $R a$ is Relay number; $P r$ is Prandtl number. For air Prandtl number $\operatorname{Pr}=0.71$; $\delta$ is the distance between the heat absorbing plate and the glass, $\mathrm{m} ; g$ is acceleration of gravity, $\mathrm{m} / \mathrm{s}^{2}$; $T_{a i r}$ is coolant temperature, $\mathrm{K} ; T_{g}$ is temperature of the glass plate, $\mathrm{K} ; \lambda$ is coefficient of thermal conductivity of air, $\mathrm{W} /(\mathrm{m} \cdot \mathrm{K})\left(\lambda_{\text {air }}=0.026 \mathrm{~W} /(\mathrm{m} \cdot \mathrm{K})\right)$; B is temperature coefficient of volume expansion of the coolant. For gases at a small constant pressure this coefficient is $B=1 / T_{\text {air }}, K^{-1}$.

A screw is a circular twisted conoid. The scan of this figure is performed for each individual turn (Fig.3) [11].

For a known step of a screw surface, $h, \mathrm{~m}$ and outer diameter, $D, \mathrm{~m}$, length of the screw line is:

$$
Z=\sqrt{(\pi \cdot D)^{2}+h^{2}},
$$

where $D$ is external diameter of a circular twisted conoid, $\mathrm{m} ; h$ is step between two turns of a screw, $\mathrm{m} ; \Omega$ is number of turns of the screw. 

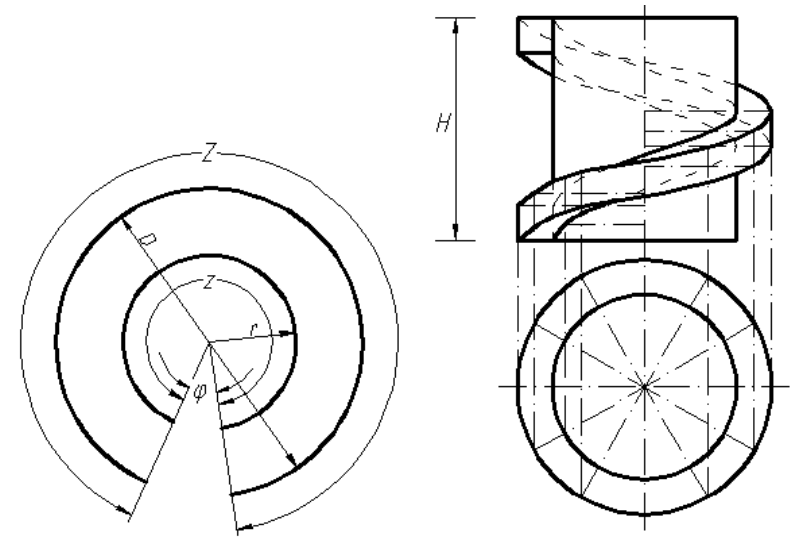

Fig.3. Spread of a ring of circular twisted conoid.

To get the area of the sweep of the turbulator spike, we need to determine the area of the segment AOB:

$$
F_{A O B}=\frac{\pi R^{2} \cdot \varphi}{360^{\circ}}
$$

where $\varphi$ is angle of the segment, hail, which is determined by such a formula [9]:

$$
\varphi=\frac{2 \pi R-h}{2 \pi R} \cdot 360^{\circ} .
$$

Then the formula for determining the surface area of the turbulator, $F_{t u r}, \mathrm{~m}^{2}$, will be as follows:

$$
F_{\text {turb }}=\left(F_{s q r}-F_{A O B}\right) \cdot \Omega=\left(\pi R^{2}-R \varphi \cdot(\pi D-h)\right) \cdot \Omega .
$$

On the basis of the obtained data (Fig.4) it can be argued that in the air channel of the solar collector there is a transitional mode of motion of the coolant, since $10^{5} \leq \mathrm{Ra} \leq 10^{9}$.

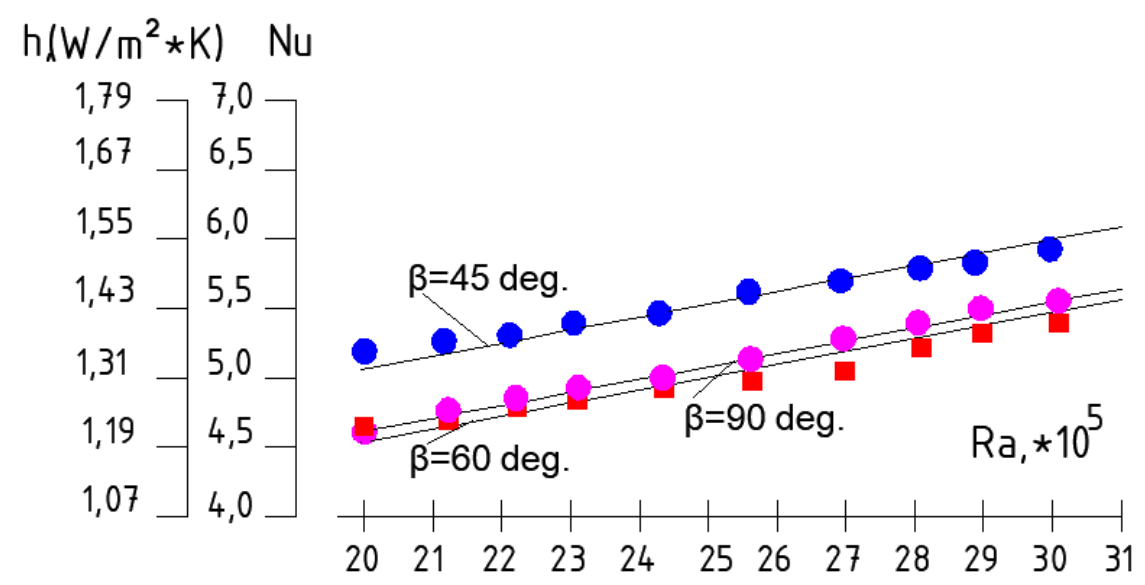

Fig.4. Dependence of the heat transfer coefficient, $h_{\text {turb-air }}, \mathrm{W} /\left(\mathrm{m}^{2} \cdot \mathrm{K}\right)$ and $\mathrm{Nu}$ numbers on the Ra number at different angles of the heat absorber.

The maximum coefficient of convective heat exchange between the flow turbulator and air was obtained at the angle of inclination of the heat absorber of 45 degrees.

The obtained values are explained by the fact that the author of the believed that at an angle of 45 degrees, the rays fall to the collector plane perpendicularly. For air-borne solar collectors, which operate on the principle of free convection, this number will be the largest in the vertical installation of SAC.

Thermal insulation. When analyzing the zone of thermal insulation, it is necessary to take into account its unchanged thermal characteristics, and take into account the thermal resistance of thermal insulation. The energy balance (formula 1) will take the form of [12]: 


$$
C_{i} \cdot m_{i} \cdot \frac{d T_{i}}{d t}=\frac{k_{i}}{\delta_{i}}\left(T_{a b s}-T_{i}\right) F
$$

Air (coolant). For the air, the energy balance will be as follows:

$$
C_{\text {air }} \cdot\left(T_{\text {air }}\right) \cdot \rho_{\text {air }} \cdot\left(T_{\text {air }}\right) \cdot L_{\text {air }} \cdot \frac{\partial T_{\text {air }}}{\partial t}=\left[h_{\text {air-g }}\left(T_{g}-T_{a i r}\right)+h_{\text {air }-a b s}\left(T_{\text {air }}-T_{a b s}\right)+h_{\text {air-turb }}\left(T_{\text {air }}-T_{\text {turb }}\right)\right] F \text {. }
$$

So, for a solar collector, the system of balance equations will be as follows:

$$
\begin{aligned}
& \left\langle Q_{g}=C_{g} \cdot m_{g} \cdot \frac{d T_{g}}{d t}=\left[h_{g-a m b, r}\left(T_{a m b}-T_{g}\right)+h_{w}\left(T_{a m b}-T_{g}\right)+h_{a b s-g, r}\left(T_{a b s}-T_{g}\right)+h_{t u r b-g, r}\left(T_{t u r b}-T_{g}\right)+\alpha I\right] F ;\right. \\
& \left\{\begin{array}{l}
C_{a b s} \cdot m_{a b s} \cdot \frac{d T_{a b s}}{d t}=\left[h_{a b s-a i r}\left(T_{a i r}-T_{a b s}\right)+\frac{k_{i}}{\delta_{i}}\left(T_{i}-T_{a b s}\right)+h_{g-a b s, r}\left(T_{g}-T_{a b s}\right)+S\right] F_{a b s} ; \\
C_{a} \cdot m_{a b} \cdot \frac{d T_{\text {turb }}}{d t}=[h
\end{array}\right. \\
& \left\{\begin{array}{l}
C_{\text {turb }} \cdot m_{\text {turb }} \cdot \frac{d T_{\text {turb }}}{d t}=\left[h_{\text {turb-air }}\left(T_{\text {turb }}-T_{\text {air }}\right)+h_{g-t u r b, r}\left(T_{g}-T_{\text {turb }}\right)+S\right] \cdot F_{\text {turb }} \cdot n \\
C_{i} \cdot m_{i} \cdot \frac{d T_{i}}{d t}=\frac{k_{i}}{\delta_{i}}\left(T_{a b s}-T_{i}\right) F_{a b s}
\end{array}\right. \\
& C_{\text {air }} \cdot\left(T_{\text {air }}\right) \cdot \rho_{\text {air }} \cdot\left(T_{\text {air }}\right) \cdot L_{\text {air }} \cdot \frac{\partial T_{\text {air }}}{\partial t}=\left[h_{\text {air-g }}\left(T_{g}-T_{\text {air }}\right)+h_{\text {air-abs }}\left(T_{\text {air }}-T_{\text {abs }}\right)+h_{\text {air-turb }}\left(T_{\text {air }}-T_{\text {turb }}\right)\right] F .
\end{aligned}
$$

Since the received system of balance equations is rather complex and contains many unknown components, computer simulation of heat processes occurring in its air channel was performed (Fig.5).

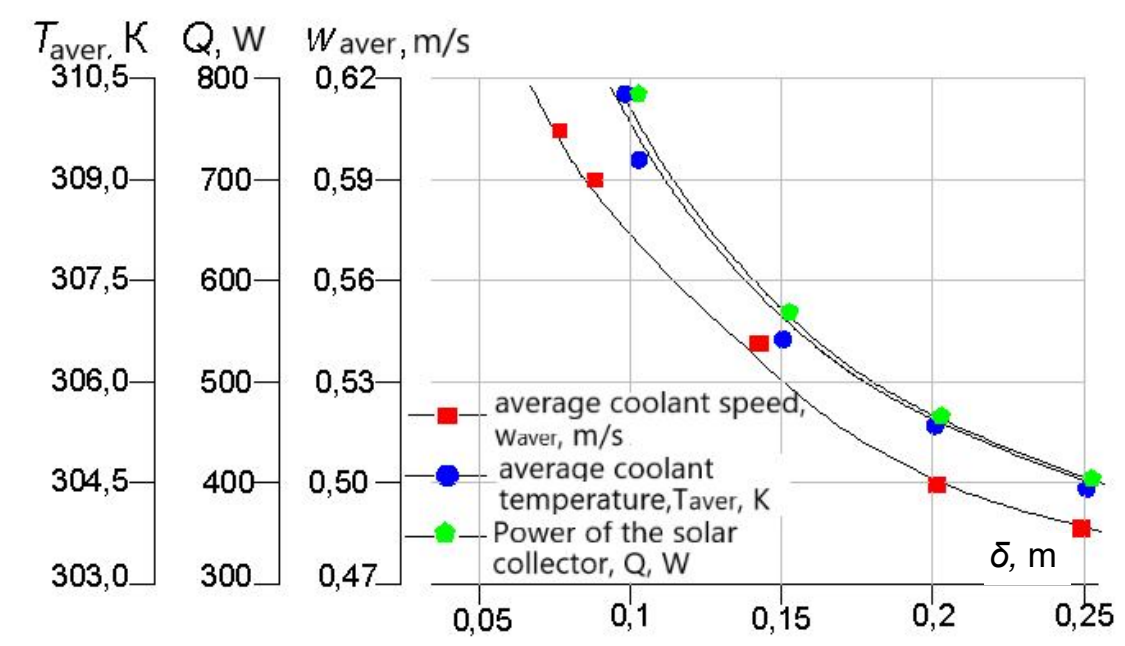

Fig.5. Dependence of average temperature $T_{\text {aver }}, \mathrm{K}$ and the average coolant velocity $w_{\text {aver }}, \mathrm{m} / \mathrm{s}$ at the outlet of the solar collector and the power of the solar collector with turbulators of the flow $Q, \mathrm{~W}$ on the height of the air channel $\delta, \mathrm{m}$.

Studies have been conducted for SAC of two modifications. In the first case the conditions of operation of the collector with a flat heat-absorbing plate were considered. As an alternative, a design with a circular crochet hook with an outer diameter of $0.05 \mathrm{~m}$ was proposed as a flow turbulator and an additional heat absorber. The results are presented as the dependence of the change in average temperature, $T_{\text {aver }}, \mathrm{K}$, average speed, $w_{\text {aver }}, \mathrm{m} / \mathrm{s}$, coolant at the outlet from the solar collector and the power of the solar collector with flow turbulators, $Q, \mathrm{~W}$, from the height of the air channel. The temperature and velocity of the coolant at the outlet from the collector and the power of the SAC were found to be maximal for the height of the air channel of $0.08 \mathrm{~m}$ (Fig.5). In addition, for an alternative option, an increase in power by $23 \%$ compared to a solar collector with a flat heat-absorbing plate is observed.

\section{Conclusion}

In this article, the main groups of solar air heating systems and their areas of effective use are presented. The physical model of the air solar collector with additional installed flow turbulators is presented, which is executed in 
the form of a circular twisted conoid to improve the heat engineering parameters of the air heater. The system of balance equations is presented with allowance for the main elements of the air solar collector. In addition, a number of dependencies were obtained for the determination of heat engineering and geometric parameters of flow turbulators. Particular attention was paid to determining the coefficient of convective heat exchange between turbulator by current and heat carrier at different angles of the heat absorber.

On the basis of the conducted studies it can be argued that in the air channel of the solar collector, there is a transitional mode of movement of the coolant, since Relay number is within $10^{5} \leq \mathrm{Ra} \leq 10^{9}$. We found out that the maximum coefficient of convective heat exchange between a turbulator of flow and air is observed in the angle of inclination of the heat absorber of 45 degrees. The computer simulation of thermal processes occurring in the air channel of the solar collector has been performed and showed that the maximum thermal power of the proposed SAC is observed at an air channel height of $0.08 \mathrm{~m}$ and is higher by $23 \%$ compared with the thermal power of the solar collector with a flat heat-absorbing plate.

\title{
References
}

[1] Shapoval S.P., Venhryn I.I. (2014) The future viability of solar energy in Ukraine. Magazine Plumbing, Heating, Air Conditioning, 8, p.1-4. (in Ukrainian)

[2] Butuzov V.A. (2013) Solar Heat Supply in the World and in Russia. Magazine Plumbing, Heating, Air Conditioning, 8, p.1-4. (in Russian)

[3] Butuzov V.A. (2013) Air Solar Collectors. Magazine Plumbing, Heating, Air Conditioning, 7, p.1-5. (in Russian)

[4] Fakhretdinova E.M. (1984) Development and research of solar installations for the drying of agricultural products: Undergraduate thesis: 05.14.05. Scientific and Production Association "The Sun", Ashgabat, 147 p. (in Russian)

[5] Kozak Ch., Savchenko O., Zhelykh V. (2016) Analysis of Heat Flow Distribution in the Room with Installed Solar Air Heater. Thermal Engineering, Heat Supply, Ventilation: proceedings of Polish Association of Sanitary Engineers and Technicians, V. 45, No. 9, p. 359-362. doi: http://yadda.icm.edu.pl/baztech/element/bwmeta1.element.baztech-8832c7f0-5cc3-4438-81d4-fe023558704d.

[6] Zhelykh V.M., Lesyk Ch. (2012) Thermosyphon Solar Collector. Patent for utility model of Ukraine No. 68773 UA MPK F24J 2. Industrial Property, No. 7; stated. 09/26/2011; has published Apr 10, 2012, Bul. No. 7 (in Ukrainian).

[7] Fabio S. (2008) Analysis of a Flat-plate Solar Collector. Heat and Mass Transport, Lund, Sweden, p. 1-4.

[8] Ahmad M. Saleh. (2012) Modeling Of Flat-Plate Solar Collector Operation In Transient States. Purdue University, Fort Wayne, Indiana, 73 p.

[9] Duffie J. A., Beckman W. A. (2013) Solar Engineering of Thermal Processes. Solar Energy Laboratory University of Wisconsin-Madison, $4^{\text {th }}$ edition, $928 \mathrm{p}$.

[10] Bennamoun L. (2012) An Overview on Application of Exergy and Energy for Determination of Solar Drying Efficiency. International Journal of Energy Engineering, V. 2(5), p. 184-189.

[11] Vysotskaya N. N, Jerusalem A. M., Nevelson R. A., Fedorenko V. A. (1968) Technical scans of sheet metal products. Mechanical Engineering, 272 p. (in Russian).

[12] Yurkevych Y. S, Savchenko O. O., Kasynets M. Y (2012) Improving of the room heat regime at the solar panel using. Motrol. Automotive and Power Industry of Agriculture, V. 14(6), p. 3-6.

\section{Фізичне моделювання теплових процесів повітряного сонячного колектора із турбулізаторами потоку}

\author{
Василь Желих, Христина Козак, Олександра Дзерин, Володимир Пашкевич \\ Національний університет «Львівська політехніка», вул. С. Бандери 12, Львів, 79013, Украйна
}

\section{Анотація}

Виконано аналіз існуючих систем сонячного повітряного теплопостачання. Представлено фізичну модель повітряного сонячного колектора (ПСК) із додатково встановленими турбулізаторами потоку, які розміщено у повітряному каналі сонячного колектора для покращення його теплових характеристик та ефективного використання у регіонах з помірним кліматом. Наведено енергетичні баланси для п'яти ключових елементів ПСК та записано систему балансових рівнянь. Для визначення геометричних та теплотехнічних параметрів турбулізаторів потоку записано ряд графічних залежностей. Визначено, що в повітряному каналі сонячного колектора спостерігається перехідний рух теплоносія, а максимальний коефіцієнт конвективного теплообміну між турбулізатором потоку та повітрям спостерігається за куга нахилу теплопоглинача 45 градусів. Здійснено комп'ютерне моделювання теплових процесів, які відбуваються у повітряному каналі сонячного колектора і отримано, що потужність запропонованого ПСК зросла на 23 \% порівняно із сонячним колектором 3 плоскою теплопоглинальною пластиною.

Ключові слова: повітряний сонячний колектор; фізична модель; турбулізатор потоку; теплоносій; повітряний канал. 